\title{
Kent Konseylerinin Yerel Demokrasiye Katkısı: Kent Konseyleri Üzerine Bir Araştırma
}

\section{Contribution of City Councils to The Local Democracy: A Research on City Councils}

\author{
Doktora Öğrencisi Hasan AKSU (iD) 1 , Doç. Dr. Abdullah TAŞTEKİN (iD)2
}

\begin{abstract}
$\ddot{O} \mathbf{z}$
Kent konseyleri, yerelde demokratik katılımın sağlanması, kentsel bilincin geliştirilmesi, kentin temel sorunların çözülmesinde ortak aklın oluşturulması, hemşeri ve kentli haklarının geliştirilmesi, kent kaynaklarının etkili ve verimli kullanılmasına katkı sağlaması, kentin hem sorunlarını çözmede hem de gelecek ile ilgili stratejik planların yapılmasında kentte ortak aklın oluşmasına yardımcı olmak amacıyla kurulmuş gönüllülük esasına dayanan yerel meclislerdir. Yerelde Belediye yönetimine hemşerilerin katılımına imkân veren kent konseyleri, bu temel hedeflerin hangi düzeyde gerçekleştirildiğinin ve demokrasiye olan katkısının ortaya çıkartılıp araştırılması, çalışmanın temel hedefini oluşturmaktadır. Araştırmanın amacına uygun olarak, kent konseylerinin yerel demokrasi üzerindeki etkisini ölçmek için örneklemdeki kent konseyleri ile anket çalışması yapılmıştır. Çalışma örneklemini, Türkiye'deki kent konseylerini kapsamaktadır. Çalışma sonucunda kent konseylerinin yerel demokrasiyi güçlendirdiğine, ancak kent konseylerinin kent ile ilgili almış olduğu kararların belediyelerce dikkate alınmadığı görülmüştür.
\end{abstract}

Anahtar Kelimeler: Kent konseyi, yerel demokrasi, katılım

Makale Türü: Araştırma

\begin{abstract}
City councils are local parliaments based on volunteer work and are constituted in order to support participation to local democracy, develop a civic consciousness, generate a common sense while solving basic problems of the city, develop the right of town-dwellers and townsman, to contribute to the usage of city sources effectively and productively and help to form a common sense while both solving the city problems and making strategical plans related to the future. City councils, which enable the townsmen to participate in the local municipality administration is the main purpose of this study by searching of the realization degrees and its contribution to the democracy. According to the aim of the study, a survey has been performed with exemplary councils in order to me a sure the effect of city councils on local democracies. The sample of research includes the metropolitan city councils in Turkey. As a result of the study, it was seen that city councils strengthened local democracy, but the decisions of city councils regarding the city were not taken into consideration by the municipalities.
\end{abstract}

Keywords: City council, local democracy, participation

Paper Type: Research

\footnotetext{
${ }^{1}$ Harran Üniversitesi, İktisadi ve İdari Birimler Fakültesi, aksuhasan2121@ gmail.com.

${ }^{2}$ Harran Üniversitesi, İktisadi ve İdari Birimler Fakültesi, atastekin@yahoo.com.

Atıf için (to cite): Aksu, H. ve Taştekin, A. (2020). Kent konseylerinin yerel demokrasiye katkısı: Kent konseyleri üzerine bir araştırma. Afyon Kocatepe Üniversitesi Sosyal Bilimler Dergisi, 22(TBMM'nin 100. Yılı ve Millî İrade Özel Sayıs1), 190-203.
} 


\section{Giriş}

Yerel yönetimlerde demokrasinin etkin ve katılımcı bir şekilde uygulanabilmesi için hemşerilerin yerel hizmet ve yerel aktivitelerde aktif bir şekilde rol alması gerekmektedir. Yerel yönetimlerde hemşeriler, kent konseyleri yoluyla yönetim sürecine katılma firsatını bulmaktadırlar. Katılımcı demokrasinin yerelde uygulama araçlarından olan kent konseyleri sayesinde bireyler alınan kararlara katılmaktadır. Bu katılım beraberinde demokrasinin yerel yönetimlerde daha etkili bir şekilde uygulanma alanı bulmasını sağlamaktadır.

Yerel Gündem 21 etkinlikleri kapsamındaki çalışmalar ile kent konseylerinin önemi artmıştır. Belediyelerin bünyesi altında varlığını sürdüren kent konseyleri, yerel katılımın teşviki için son derece önemli bir yapıya sahiptir. Yerel yönetimlerde halk, yapılacak olan faaliyetler için bir araya gelecek ve ortak çıkarlar doğrultusunda karar alma firsatı bulacaktır. Halkın bu alanlarda ortak karar alması ve bu kararları etkili bir biçimde kullanması beraberinde kolektif yararı getirecektir. Bu kararlar ile bireysel, kişisel faydanın önüne geçilmiş olup toplumsal fayda sağlanmış olacaktır. Böylece bireylerin demokrasiye olan güven duygusu artacaktır.

Kent konseyleri aracılığıyla bir araya gelen bireyler, sivil toplum kuruluşları ve kamu kuruluşları kent ile ilgili ortak kararlar alacakları için, doğal olarak kentin tümünü temsil eden geniş tabanlı bir katılım sağlanmış olacaktır. Dolaysıyla bu geniş tabanlı katılım süreci, kentte meydana gelecek her türlü faaliyet ve ilişkilerde ortak bir aidiyet bilincinin gelişimine imkân sağlayacaktır.

Türkiye'de 1990'lı y1llardan sonra Yerel Gündem 21 programı çerçevesinde yerel meclisler oluşturulmuştur. 5393 sayılı Belediye Kanunu ile yerel gündem yapılanmaları kent konseylerine dönüştürülmüştür. Bu yasal düzenleme gereği bazı kentlerde bu yönde çalışmalar olsa da henüz bütün kentlerde istenilen seviyeye ulaştığını söylemek çok zordur. Ancak demokratik bir düzen ve yerel halkın katılımı bağlamında kent konseyleri bir an önce gerekli seviyeye getirilmeli ve bu çalışmalara öncelik tanınmalıdır. Bu tip yerel örgütler ile yerel yönetimlerde katılım konusunda gelişmeler yaşanacak ve bu durum yerel yönetimlerin demokratikleşmesine önemli fayda sağlayacaktır. Bu kapsamda çalışmada, kavramsal alt yap1 olarak yerel yönetimler, demokrasi, yerel demokrasi, kent konseyi, kent, katılım kavramları açıklanmıştır. Akabinde kent konseylerinin yerel demokrasinin gelişimine olan katkısı açıklanmıştır. Çalışma kent konseyleri üzerinde yapılan alan araştırması sonucu elde edilen verilerin yorumlanması ile sonuçlandırılmıştır.

\section{Kavramsal Çerçeve}

Bu bölümünde öncelikli olarak çalışmanın teorik temellerini oluşturan yerel yönetimler, kent, demokrasi, yerel demokrasi, katılım ve kent konseyleri kavramlarının açıklanmasına yer verilmiştir.

\subsection{Yerel Yönetimler}

Bir ülkede yönetsel faaliyetler ve hizmetler devletin tüzel kişiliğinde yerine getirilmekte ya da belirli bir kısmı genel yönetim dışında özerk yönetsel kuruluşlara verilmektedir. 1982 Anayasa'sında (mad. 123), yönetimin kuruluş ve görevlerini yerine getirirken merkezden yönetim ve yerinden yönetim ilkelerinin esas alınacağ 1 belirtmiştir (Gözübüyük, 2006, s. 94). Yerinden yönetim ilkelerine uygun olarak uygulanan yerel yönetimler, yerel katılımı sağlanması, demokrasinin uygulanması ve yerel hizmetlerin aktif bir şekilde uygulanması için önemli bir işleve sahiptir. Bu doğrultuda yerel yönetimler, toplumların ya da yerel birimlerdeki halkın, ekonomik, sosyal, siyasal, idari yapısının yanında, demokrasi kültürünün topluma yerleştirilmesinde önemli bir rol oynamaktadır. Dolayısıyla yerel yönetimler, toplumsal yapılara demokratik değerlerin kazandırılmasında, yönetimde etkin katılımın sağlanmasında ve bu 
değerlerin verimli bir şekilde sağlanmasında önemli bir rol üstlenmektedir (Memişoğlu, 2015, s. 51-52).

Yerel yönetimler, belli ihtiyaçlara ve hedeflere ulaşabilmek için, toplumların süreç içerisinde ihtiyaçlarına cevap veren idari ve özerk birimlerdir. Yerel yönetimlerin karşıladığı bu ihtiyaçlar; idari, siyasi, toplumsal özellikler taşıyan gereksinimlerdir (Keleş, 1998, s. 19-20). Diğer bir ifade ile yerel birimlerde hizmetleri yerine getirmek için il özel idaresi, belediyeler ve köylere yasalarla verilmiş olan yetkiler çerçevesinde zorunluluk veya isteğe bağlı kalınarak, toplumda alınmış olan ortak kararları yürütmek üzere kurulmuş, kamu tüzel kişiliğine sahip birimlerdir (Taştekin, 2015, s. 157).

Yerel yönetimler, yerel demokrasinin gelişmesine ve alınacak olan kararlarda halkın yönetimde söz sahibi olmasına yaptığı katkıdan dolayı önemli bir işlev üstlenmektedir. Yerel yönetimlerde alınacak olan kararlar mekânsal uzaklık olarak da halk yönetime yakın olduğu için yönetenler doğrudan denetlenebilmektedir (Pustu, 2005, s. 124). Bu kapsamda yerel yönetimler, yerelde demokrasi ve katılım kültürü oluşturarak hemşerilik bilincinin gelişmesine katkıda bulunmaktadir.

\subsection{Kent}

Yerel yönetimin daimi öznesi kenttir. Bu açıdan bakıldığında, kent ve yerel yönetim yapıları itibari ile birbirlerine çok benzemektedir. (Parlak, 2015, s. 6). Kent, insanların karşılıklı olarak birbirleriyle sürekli bir bağ içerisinde bulunmaları sonucu meydana gelmiştir. Kısacası kent sürekli bir iletişim ve etkileşim alanıdır (Bağlı ve Binici, 2005, s. 20). Kent, bir toplumu hem içsel hem de dişsal alandan etkileyip ve bu süreçte bu faktörlerden etkilenen, toplumun dinamik yapısına rehberlik eden sosyolojik bir yapıdır. Karşılıklı bir etkileşim ve iletişim çerçevesinde yaşam alanı bulan yapıdır (Harwey, 2012, s. 174). Lefebre'de kenti, stratejik konumunun getirmiş olduğu etkenin sonucunda yapısında farklılığı barındıran, etrafındaki diğer yapılarla bir etkileşim içinde bulunan, buna göre ilişki seviyesinin ve arz talep yapısının ne olduğunu belirleyen bir yaşam alanı olarak tanımlamıştır (Lefebre, 2013, s. 48). Kent, sahip olduğu nüfus yapısı itibari ile birincil ekonomik faaliyetlerle kendini ifade eden, tarımsal toplum yapıs1 yerine sanayi ve hizmet sektörlerinin etkin olduğu toplumsal yapıyı ifade etmektedir (Şahin, 2010, s. 3). Bu geçişkenliği ile birlikte kentin değeri sahip olduğu toprak parçası ile değerlendirilmiştir. Kent, dışsal alan özelliği ile fiziksel çevreyle çelişen tarımsal faaliyetlerin az olduğu, nüfus bakımından yoğun olan yerleşim yeridir. Peker kenti, tabiatı olduğu gibi kabul etmeyip, kendini tabiattan daha yükseklerde bulan yapı olarak görür (Peker ve diğerleri, 2016, s. 286).

\subsection{Demokrasi ve Yerel Demokrasi}

Yerel yönetim ve kent tanımlamalarından sonra diğer önemli kavram ise demokrasidir. Demokrasi, halkın egemenliğini temsil eden siyasi bir yönetim biçimidir (Sunar, 2010, s. 17). Bir yönetim biçimi olan demokrasi, kamuyu yakından ilgilendiren temel sorunlar ile ilgili alınacak olan kararlarda tüm halkın doğrudan ya da dolaylı olarak sürece dâhil olduğu bir siyasal yapıyı ifade eder (Kocaoğlu, 2015, s. 21).

Demokratik düzenlerin gelişmesiyle beraber farklı etnik yapıya sahip grupların sorunları ortaya çıkmaktadır. $\mathrm{Bu}$ sorunlarla yüzleşen gerek dini gerekse laik gruplar, amaçlarına ulaşabilmek için etkili olarak kullanabildikleri araçları hılı bir şekilde devreye sokarlar. Statükocu yapılar, birbirinden farklı heterojen yapıya sahip ve karmaşı yapılı muhalif gruplar arasında sürekli bir etkileşim söz konusudur. İşte tüm farklılıklar ancak demokrasinin varlığını sürdüğü yapılar içerisinde etkisini hissettirebilir (Küçükyılmaz, 2011, s. 14). Demokrasi, insanların istekleri ve tercihleri sonucu oluşmuş demokratik değerler bütünü olarak betimlenebilir (Çukurçayır, 2012, s. 23). Gerçek anlamda işlevini devam ettiren demokrasi, beraberinde katılımcılığ 1 işlevsel hale getirecektir. Bu tür işleyişlerin sonucunda toplumda demokratik bir yap1 meydana gelecektir (Arslan, 2001, s. 84). Toplumlar bu demokratik 
değerlere doğrudan demokrasi, temsili demokrasi ve yarı doğrudan demokrasi araçlarıyla ulaşabilmektedir (Gözler, 2017, s. 108).

Demokrasi hakkında yapılan çeşitli tanımlamalar şüphesiz yerel demokrasi içinde yapılmaktadır. Yerel demokrasi kavramı üzerinde çeşitli tartışmalar olmakla birlikte, kavramın yanlışlığı ve eksikliği üzerinde farklı düşünceler belirtilmektedir. Yerel demokrasi kavramı daha çok "demokratik yerel yönetim" şeklinde telaffuz edilmektedir (Görmez, 1997: 67-68). Bu kapsamda yerel demokrasiyi, "demokratik değerlerin yerel yönetimler için geçerli kılınması" şeklinde tanımlamak mümkündür (Görmez, 1997, s. 70).

Yerel demokrasi sözcüğü için yönetimdeki demokratik değerler üzerinde durulduğu görülmektedir. Bazen bu kavramın yerel özerklik kavramıla bir tutulup aynı anlamda kullanıldığı da görülür. Yerel demokrasi, yerel birimlerde aktif bir yönetim anlayışını benimseyen, etkinlik ve faaliyetlerde demokratik değerleri ön planda tutan, demokrasinin bünyesinde var olan birçok değeri benimseyen katılımcı bir yapıdır. Bu kavram, içinde bulunulan toplumun demokratik açıdan özgürleşmesine olanak veren değerler bütünü olarak da tanımlanabilir (Görmez vd., 2011, s. 37).

\subsection{Kent Konseyleri ve Katılım}

Yerel demokrasinin aktif işlenmesi ile birlikte alınan kararlarda katılım olgusu ön plana çıkmaktadır. Katılım gerçek anlamda bir katılma duygusudur. Katılım, yapılan aktivitelere, toplumsal ve kültürel olan faaliyetlere katılmayı, var olanı da birlikte paylaşmayı ifade eder (Kaypak, 2011, s. 136). Toplumda meydana gelen değişimler ile birlikte demokrasinin içeriği ve yapısal işlevinde bir değişim yaşanmıştır. Bu değişimler; halkın siyasal katılım ile gücünü temsili olarak teslim ettiği bir yönetim anlayışının varlığıdır. Bu yönetim anlayışı tüm toplumun beklentilerinin karşılanması için, alınacak olan kararlarda halkın düşüncelerine başvurulmasını öngörmektedir. (Akdeniz, 2007, s. 13). Katılım, toplumun ve yönetimin alınacak olan kararlarda yerel halkın etkin katılımının sağlanması demektir. Katılımın amacı, demokrasiye olan güveni sağlamasının yanında, halkı ilgilendiren konularda alınan kararların emir niteliğinden çıkartılıp, bu kararları yerel halka mal etmektir (Çevikbaş, 2008, s. 74).

Yerel yönetimlerde katılımın sağlanması ve yerel halkın her aşamada karar alma süreçlerinde yer alması için aktif bir katılımın olması gerekir. Dolayısıyla kent konseyleri bu aşamada önemli bir işlev üstlenmektedir. Kent konseyleri, merkezdeki hükümetin uygulayacağ1 kamu politikalarında ya da alınacak olan kararlarda yerel yönetim, sivil toplum kuruluşları vb. kamu kurumu niteliğinde bulunan kurumlar ile bir araya gelmektedir. Bu yapısı itibari ile kent konseyi, toplumsal yapı ile ilgili ortak kararların alındığı, kentin sorunlarının dile getirildiği, kentin gelecekte karşılaşabileceği sorunlar hakkında değerlendirilmelerin yapıldığ 1 , alınan kararların demokratik bir süreç içerisinde katılımcı bir anlayışla değerlendirildiği, bünyesinde bulunan farklı organlardan oluşan sivil toplum kuruluşlarıdır (Baran, vd., 2011, s. 190).

\section{Kent Konseylerinin Yerel Demokrasinin Gelişimine Katkıları}

Kent konseyleri, kentlerde kentlileri ilgilendiren kararların alımında ve ortak fikirler doğrultusunda hareket edilmesini, ortak yaşam biçiminin oluşturulmasını, kentlinin kentine sahip çıkmasını, halkın yönetime katılımını sağlamasını, yerel halkın kentle ilgili görüşlerini ve düşüncelerini açık bir şekilde ifade etmesine yardımcı olan demokratik değerler bütününü ifade etmektedir.

1970'li yıllardan sonra nüfusun hılı artması kentleşme ve beraberindeki hızlı sanayileşme çabaları sonucu, insanoğlunun çevreye verdiği zarar artmıştır. Bu durum beraberinde çevre sorunlarına olan hassasiyeti ve duyarlılığ artırmıştır. Birleşmiş Milletlerin 1972, 1992, 2002 ve 2012 yıllarında yapmış olduğu zirveler ile insanlığın, çevreye vermiş olduğu zararları en aza indirmeyi ve gelecek nesillerin de yaşam haklarını güvence altına alarak sürdürülebilir bir yaşam geliştirmeyi amaçlamıştır. Bu kapsamda, özellikle 1992 yılında Rio'da gerçekleştirilen YG 21 Programı önemlidir. YG 21 Programının temel amacı; insanın temel 
ihtiyaçlarının karşılanması, sağlıklı bir ekosistemi inșa etmek, gelecek nesillerin de haklarını koruyarak bu doğrultuda çalışmalar yapmak, çevre ve ekoloji arasındaki dengeyi sağlayan köprü görevini üstlenmektir. (Ulusoy ve Tekdere, 2015, ss. 48-75).

1992 yılından sonra birçok ülke YG 21 Programının getirmiş olduğu değişimler ve bu değişimlerin yansıması olan ilkeleri uygulamaya başlamıştır. Türkiye'de bu uygulamalar 1996 yılından sonra İstanbul'da düzenlenen BM Habitat II İnsan Yerleşimleri Konferansı sayesinde olmuştur. Bu konferans ile yerel yönetimler, YG Gündem 21 programının getirmiş olduğu katılımcı anlayışı ve kentlinin kentini sahiplenmesini sağlamaya çalışmıştır. Birleşmiş Milletler Kalkınma Programı'nın (UNDP) desteği ile yürütülen ve IULA-AMME tarafından Bursa Büyükşsehir Belediyesi iş birliği çerçevesinde gerçekleştirilen "Türkiye' de YG 21'lerin Teşviki ve Geliştirilmesi” projesi ile demokratik değerler konusunda Türkiye uluslararası bir adım atmaya çalışmıştır (Üzan, 1999, s. 98).

Türkiye'de kent konseyine ilişkin yasal düzenleme 2005 tarihli 5393 sayılı Belediye Yasası'dır. Bu yasa (76. Mad) ile kent konseylerine; "kent yaşamında; kent vizyonunun ve hemşerilik bilincinin geliştirilmesi, kentin hak ve hukukunun korunması, sürdürülebilir kalkınma, çevreye duyarlılık, sosyal yardımlaşma ve dayanışma, saydamlık, hesap sorma ve hesap verme, katılım ve yerinden yönetim ilkelerini hayata geçirmeye çalışır" (KKY, Mad. 76). $\mathrm{Bu}$ yasa ile birlikte kent konseylerinin demokratik değerlerler konusunda üstlenmiş olduğu görev açık bir şekilde belirtilmeye çalışılmıştır.

$\mathrm{Bu}$ yasa sonrası kent vizyonu için önem arz eden kent konseyi mevzuatının oluşturulması için 2006 yılında Kent Konseyi Yönetmeliği çıkarılmıştır. Bu kapsamda kent konseyi, "merkezi yönetimin, yerel yönetimin, kamu kurumu niteliğindeki meslek kuruluşlarının ve sivil toplumun ortaklık anlayışıyla, hemşerilik hukuku çerçevesinde buluştuğu; kentin kalkınma önceliklerinin, sorunlarının, vizyonlarının sürdürülebilir kalkınma ilkeleri temelinde belirlendiği, tartışıldığı, çözümlerin geliştirildiği, ortak akıl ve uzlaşmanın esas olduğu demokratik yapılar ile yönetişim mekanizmalarıdır" (KKY, Mad. 4/b.) şeklinde ifade edilmiştir.

Kent konseyi yönetmenliği 'ne (8. Mad) göre, kent konseyleri şu birimlerden oluşmaktadır. Mahallin en büyük mülki idare amiri veya temsilcisi, belediye başkanı veya temsilcisi, sayısı 10'u geçmemek üzere illerde valiler, ilçelerde kaymakamlar tarafindan belirlenecek kamu kurum ve kuruluşlarının temsilcileri, mahalle sayısı 20'ye kadar olan belediyelerde bütün mahalle muhtarları, diğer belediyelerde belediye başkanının çağrısı üzerine toplanır. Toplanan mahalle muhtarlarının toplam muhtar sayısının \% 30'unu geçmemek ve 20 'den az olmamak üzere kendi aralarından seçecekleri temsilcileri, beldede teşkilatını kurmuş olan siyasi partilerin temsilcileri, üniversitelerden ikiden fazla olmamak üzere en az bir temsilci, üniversite sayısının birden fazla olması durumunda her üniversiteden birer temsilci, kamu kurumu niteliğindeki meslek kuruluşları, sendikalar, noterler, baro, kooperatifler, birlikler, konuyla ilgili dernek ve vakıf temsilcileri, kent konseyince kurulan meclis ve çalışma gruplarının birer temsilcisinden oluşmaktadır (KKY, Mad. 8).

Kent konseyleri belirtilen bu faaliyetleri yerine getirmek için belirli görevlere sahiptir. Bu kapsamda kent konseylerinin görevleri şu şekildedir (KKY, Mad. 6);

$\checkmark$ Yerel yönetimlerde halkın katılımının yaygınlaştırılması,

$\checkmark$ Bir arada yaşayan bireylerin hemşerilik bilinci etrafında bir araya getirtilerek bu anlayışın geliştirilmesi,

$\checkmark$ Toplumda çok yönlü yönetişim anlayışının gelişmesine katkıda bulunmak,

$\checkmark 2009$ yılında yönetmelikte yapılan değişiklik çerçevesinde sürdürülebilir gelişim anlayışının sağlanması veya bu çerçevede ortaya çıkabilecek olası sorunların tahminini yaparak bu sorunların önüne geçmek ya da ilerisi için önlem almak (Resmi Gazete, 06. 06. 2009). 
$\checkmark$ Kente yönelik yapılan veya yapılacak olan strateji ve planlamalarda tüm kentlilerin fikrini alarak ortak yaşam bilincini geliştirmek,

$\checkmark$ Subsidiarite (hizmette yerellik) ilkesi gereğince yerel yönetimlerde ve kentlerde katılım kültürünü geliştirip halka yansıtmak, demokrasi ve ortak akıl olan uzlaşma kültürünü geliştirmek,

$\checkmark$ Kentin tarihsel süreç içerisinde kazanmış olduğu temel özellikleri, doğal güzellikleri vb. gibi benzeri değerlere sahip çıkılmasını sağlamak,

$\checkmark$ Kent yönetiminde saydamlık, katılım, hesap verilebilirlik, şeffaflık ilkelerinin uygulanmasını sağlamak veya uygulanmasına destek vermek,

$\checkmark$ Kent konseyince alınan kararların değerlendirilmesi ve belediye yönetimlerine gönderilmesini sağlamak,

$\checkmark$ Kent kaynaklarını adil, etkin, sürdürülebilir bir politika çerçevesinde kullanılmasına katkı sağlamak. Sürdürülebilir politikalar çerçevesinde kentin yaşamsal alanlarında yaşam kalitesini artırmak, çevreye duyarlı plan ve program üretmek, yoksullukla ilgili alınmış olan programlara destek vermek,

$\checkmark$ Sivil toplum kuruluşlarının gelişmesine destek vermek ve bu kurumların kurumsal bir anlayış kazanmasına destek vermek,

$\checkmark$ Kentte yaşayan kadın, çocuk, genç, engelli vb. tüm vatandaşların toplumsal yaşam kalitelerini geliştirmek, alınacak olan kararlarda tüm vatandaşların katılımını sağlamaktır.

$\checkmark$ Belirtilen bu hususların mevzuata alınması önem arz etmektedir. Ancak belirtilen bu hususların uygulamada kendini hissettirmesi ve demokratik değerlerin oluşmasına imkân sağlaması için bu hususlar halka benimsetilmeli ve uygulamada etkisi artırılmalidır.

Kent konseyleri, Belediyelerin olduğu alanlarda, yerel yönetimler seçimlerini takip eden 90 gün içerisinde ve (8.md) belirtilen kriterlere göre üye seçimi yapılır. Kent konseyleri genellikle ilk görüşme ve toplantısını, yerel birimdeki belediye amirinin daveti üzerine yapar. Belediye Başkanı başkanlığında bir araya gelen üyeler toplantının düzenli ilerlemesi için kendi içlerinden minimum üç üye seçerek divan kurulunu oluştururlar. Divan kurulu oluşturulduktan sonra kent konseyi yürütme organı ile kent konseyi başkanın seçimi de yapılır (Emrealp, 2010, ss. 18-19).

Kent konseyi; genel kurul, yürütme kurulu, meclisler ve çalışma gurupları ile başkan ve genel sekreter organlarından oluşmaktadır. Kadınlar meclisi, gençlik meclisleri, çocuk meclisleri, yaşlı meclisleri engelliler meclisleri gibi çeşitli demokratik değerler ile toplumsal katmanları içerisinde bulunduran çalışma meclisleri bulunmaktadır. Ayrıca kent konseyi içerisinde genel koordinasyonu sağlayan genel sekreter, kent konseyi başkanı tarafından önerilen üç aday içerisinden seçilir. Genel sekreter seçme işlemini yürütme kurulu organı yapmaktadır. Genel sekreterin görevi, personele ait hizmetleri düzenleyip, kent konseyi faaliyetlerini yürütmektir. Öte yandan kent konseyi sekretarya hizmetleri yerine getirecek olan personel belediyeler tarafindan yerine getirilmektedir (KKY, Mad. 14 ve Mad. 15).

Kent konseyi organları belirtilen çalışma yönergesi esaslarına göre belirlenen yer ve zamanlarda üye tam sayısının salt çoğunluğu ile toplanır ve katılanların salt çoğunluğu ile karar alınır. Yapılan oylamada eşitlik olması halinde ise, başkanın bulunduğu taraf çoğunluk olarak kabul edilir (KKY, Mad. 13). Genel kurulca oluşturulan görüş ya da öneriler belediye meclisinin ilk toplantısında ele alınır. Ele alınan öneriler değerlendirildikten sonra belediye tarafından kent konseyine bildirilir ve kamuoyuna belirli yayın araçları ile duyurulur (KKY, Mad. 14). Mali yapıları ise; Belediyeler, kent konseylerine bütçelerinde ödenek ayırmak suretiyle ayni ya da nakdi şekilde yardım yapar ve destek sağlar ibaresi mevcuttur (KKY, Mad. 14). 


\section{Araştırma Metodolojisi}

\subsection{Araştırmanın Amacı ve Yöntemi}

Araştırmanın amacı, kent konseylerince alınan kararların belediye yönetimleri tarafından hangi ölçüde dikkate alınıp ya da alınmadığı, katılımcıların kent konseylerinin yerel demokrasiyi güçlendirip güçlendirmediğine dair düşüncelerini ortaya koymak, yapılan kent konseyi toplantılarına katılımın nasıl gerçekleştiği ve kent konseylerinin yerel demokrasiye olan katkısını ortaya koymaktır.

Araştırmanın amacı gereği, kent konseylerinin yerel demokrasi üzerindeki etkisini ölçmek için anket çalışması yapılacaktır. Böylece kent konseylerinin yerel bağlamda alınacak olan karar mekanizmalarının önemi ortaya çıkacaktır.

Anket çalışmasının birinci bölümünde anket testi uygulanan kişilerin demografik özellikleri sorularla belirlenmeye çalışılmıştır. Bu bölümdeki sorular; cinsiyet, yaş, medeni hal, meslek, öğrenim durumu ve gelir durumu gibi bilgiler içeren sorulardan oluşmaktadır.

Anketin ikinci bölümünde ise; kent konseylerinin işlevselliğini ortaya çıkaracak ve kent konseylerinin aktiflik katılım faaliyetlerini ortaya çıartacak olan soru testlerinden oluşmaktadır.

Anket çalışması yapılan kent konseylerinden Mardin Kent Konseyi yeni oluşumundan dolayı tüm yargıları cevaplamadığından bazı tablolarda "missingsystem" olarak belirtilmiştir.

Hipotez 1:

Türkiye'de kent konseyleri tarafından alınan kararların belediye yönetimleri tarafından yeterince dikkate alınmadığı düşünülmektedir.

Hipotez 2:Yerel yönetimlerde kent konseylerinin aktifliğiyle birlikte alınan veya alınacak olan kararlarda gönüllü katılımın sağlanacağı ve demokrasinin işlevselliğinin daha da artırılacağı düşünülmektedir.

\subsection{Araştırmanın Kapsamı ve Örneklemi}

Araştırmaya konu olan kent konseyleri, başka bir deyişle, "evren" sosyal bilimlerde belirli olan yöntemlerle belirlenmiştir. Buna göre araştırmanın evrenini Türkiye'deki mevcut 315 kent konseyi oluşturmaktadır (BIMMER, 2017).

Bilimsel çalışmalarda çalışmanın yapıldığı alanın ulaşım, iletişim ve fiziksel özellikleri tespit edilmelidir (Karataş, 2015, s. 64). Araștırmada kent konseylerinin faal durumları dikkate alınarak evren ve örneklem tespit edilmiştir. Bu özelliklerden yola çıkarak Türkiye Kent Konseyi Platformu üzerinden aktif olan 77 kent konseyinden 52 kent konseyi yönetici grubuyla anket çalı̧̧ması yapılmıştır (TKKB, 2017).

Kent konseyleri seçiminde, araştırmacının öznel şartlara göre, örneği oluşturan katılımcıların çalışmanın problemlerine cevap bulabileceğine inandığ örneklem yöntemi kullanılmıştır (Seyidoğlu, 1995, s. 34). Başka bir deyişle, seçilen kent konseylerinin, çalışmanın konusunu teşkil eden sorulara cevap verebileceği düşünülerek seçilmişsir.

Araştırmada kullanılacak kota $\mathrm{Q}=52 / 77=0,67$ 'dir. Araştırmacı saptadığ katılımcıların \%67'sini örneklem olarak almıştır. Böylece çalışmada \%5'lik örneklem hatası yani $\% 95$ güvenirlik düzeyi ile örneklem seçilmiştir. Kota saptandıktan sonra belirlenen oranda kişiyle görüşme çalışmanın güvenirliği açısından önemlidir (Gökçe, 1988, s. 83).

\subsection{Araştırmanın Ölçekleri ve Verilerin Çözümlenmesi.}


Araştırmada veri toplama aracı olarak anket formu kullanılmıştır. Araştırmacı ve denekler için zaman bakımından daha kolaylık sağlanması ve deneklere daha rahat bir şekilde ulaştırılması, tutum ölçümleri ve sayısal verilerin elde edilebilmesi bakımından soru formu kullanılmıştır. Anket, kent konseylerinin yönetim tabakasında bulunan kent konseyi başkanı, başkan yardımcısı, genel sekreter, koordinatör veya meclis üyelerinden oluşan kişilere uygulanmıştır.

Araştırmada anket soruları aracılığıyla elde edilen veriler ilk olarak SPSS (Statistical PackagesforSocialScience) sistem programında oluşturulan veri kütüğüne aktarılmıştır. Buraya aktarılan veriler üzerinden araştırmada elde edilmek istenilen amaçlara uygun bir şekilde kodlanarak, istatistikî analizler yapmaya elverişli hale getirilip yorumlama yapılmıştır.

Araştırmada kullanılan anket uygulaması, Türkiye Kent Konseyi Platformu üzerinden aktif olan kent konseylerine uygulanmıştır. Bu kent konseylerini, Türkiye Kent Konseyi Platformu üzerinden aktif olan 77 kent konseyinden 52 kent konseyi oluşturmaktadır (TKKB, 2017).

\section{Araştırmanın Bulguları}

"Kent Konseylerinin Yerel Demokrasiye Katkısı: Büyükşehir Kent Konseyleri Örneği” konulu alan araştırması ile araştırmaya katılan kent konseyleri üzerinde genel bir değerlendirme yapmak mümkündür. Araştırmadan elde edilen bulgular çerçevesinde şu değerlendirmeler yapilabilir.

\subsection{Demografik Bulgular}

Yaş: Araştırmaya katılan katılımcılar \% 28,8'i "35-54" ve yine aynı oran ile "55-64" arasındadır. Bu yaş grubundan sonra \% 21,2'si“45-54” yaş gelmektedir. \% 11,5'i “25-34” yaş grubu ve son olarak \% 9,6's1 "65 ve üzeri” yaş grubundan oluşmaktadır.

Cinsiyet: Araştırmaya katılan katılımcıların \%69,2'si erkek, \% 30,8 kadındır. Araştırmaya katılanların büyük bir bölümü erkeklerden oluşmaktadır.

Meslek: Araştırmaya katılan katılımcıların \% 15,4'ü profesyonel meslek, \% 48,1'i memur, \% 26,9'u emekli ve \% 9,6's1 diğer meslek grubundan oluşmaktadır. Araştırmaya katılanların çoğunluğunu memur kesimi oluşturmaktadır. Bu durumun nedeni ise, eğitim düzeyi ile birlikte gönüllü katılımın daha da artması ve gönüllü katılımın bir öğesi olan kent konseyi yöneticiliği görevinin üstlenmesi etkili olmaktadır.

Öğrenim Durumu: Araştırmaya katılan kent konseyi üyelerinin \% 7,7'si lise, \% 13,5’i ön lisans, \% 53,8'i üniversite, \%15,4'ü yüksek lisan ve \% 9,6's1 doktora öğrenimi almış kişilerden oluşmaktadır. Araştırmaya katılanların yarısından fazlası (\% 53,8) üniversite mezunu kişilerden oluşmaktadır.

Gelir Durumu: araştırmaya katılan kat1lımc1ların\% 53,8'i “3001-4000” TL, \% 26,9'u “4001-5000” TL, \% 19,2'si “5000 ve üzeri” TL gelire sahip kişilerden oluşmaktadır.

Belediye Yönetiminin Denetiminde Olduğu Siyasi Parti: Soruları yanitlayan katılımciların 29'u (\% 55,8) Adalet ve Kalkınma Partisi (AK Parti), 20'si (\% 38,5) Cumhuriyet Halk Partisi (CHP), 3'ü $(5,8)$ ise diğer partilere mensuptur. Adalet ve kalkınma Partisinin çoğunluğu elinde bulundurmasının nedeni, mevcut konumu itibari ile iktidar partisi olmasından kaynaklanmaktadır.

Kent Konseyindeki Göreviniz: Araştırmaya katılan katılımcıların 16's1 (\% 30,8) kent konseyi başkanı, 28'i (\% 53,8) kent konseyi genel sekreteri ve 8'i $(\% 15,4)$ de koordinatörlük görevini yürüten kişilerden oluşmaktadır.

\subsection{Kent Konseylerinin Almış Olduğu Kararların Uygulanabilirliğine Dair Bulgular}


Bu bölümde kent konseylerinin toplumun demokratik yapısını güçlendirmek için almış olduğu kararların belediye yönetimleri tarafından ne ölçüde dikkate alındığı üzerinde durulacaktır.

Tablo 1. Kent kimliğine ilişkin tarihi, kültürel, doğal değerlerin korunması ve geliştirilmesine yönelik kararlar

\begin{tabular}{lcr}
\hline Alınan Kararlar & Say1 & $\%$ \\
\hline Kararlar tamamen hayata geçirildi & 19 & 43,1 \\
Kararlar kısmen uygulandı & 17 & 33,3 \\
Hiç dikkate alınmadı & 15 & 23,5 \\
Toplam & 51 & 100,0 \\
\hline
\end{tabular}

Kent kimliğine ilişkin tarihi, kültürel, doğal değerlerin korunması ve geliştirilmesine yönelik almış olduğu kararlarla ilgili katılımcılar, belediye yönetimlerinin bu kararların 19'nu (\% 43,1) "kararlar tamamen hayata geçirildi", 17'sinin (\% 33,3) "kararlar kısmen uygulandı", 15 'nin $(\% 23,5)$ de "hiç dikkate alınmadı" yanıtı vermiştir (Tablo. 1). Çoğunluk $(\% 43,1)$ kararlar tamamen hayata geçirildi yanıtı vermiş olsa da alınan kararların yeterince dikkate alınmadığı görülmüştür. Dolayısıyla kentin değerlerinin korunması ve geliştirilmesi açısından kent konseylerince alınan kararların belediye yönetimlerince yeterince dikkate alınmadığ 1 görülmüş̧ür.

Tablo 2. Ortak yaşam bilincinin geliştirilmesine yönelik çalışmalarda yönelik kararlar

\begin{tabular}{lcr}
\hline \multicolumn{1}{c}{ Alınan Kararlar } & Say1 & \multicolumn{1}{c}{$\%$} \\
\hline Kararlar tamamen hayata geçirildi & 19 & 43,1 \\
Kararlar kısmen uyguland 1 & 17 & 33,3 \\
Hiç dikkate alınmadı & 15 & 29,4 \\
Toplam & 51 & 100.0 \\
\hline
\end{tabular}

Ortak yaşam bilincinin geliştirilmesine yönelik almış olduğu kararlarla ilgili katılımcılar, belediye yönetimlerinin bu kararların 19'nu (\% 43,1) "kararlar tamamen hayata geçirildi", 17'sinin (\% 33,3) "kararlar kısmen uygulandı", 15'nin (\% 29,4) "hiç dikkate alınmadı" yanıtını vermiştir (Tablo. 2). Aynı yerde yaşayan bireylerin gelecek ile ilgili ortak fikirler etrafında birleşmesi ve gelecek nesillerin de ihtiyaçlarını düşünerek hareket etmeleri önem arz etmektedir. Bu yönüyle kent konseylerinin bu alanda almış oldukları kararlar oldukça önem arz etmektedir. Ancak tablodaki verilere bakıldığında, kent konseylerinin bu alanda almış oldukları kararlar belediye yönetimleri tarafından yeterince dikkate alınmamıştır.

Tablo 3. Sürdürülebilir gelişmeye yönelik alınan kararlar

\begin{tabular}{lcc}
\hline \multicolumn{1}{c}{ Alınan Kararlar } & Say1 & $\%$ \\
\hline Kararlar tamamen hayata geçirildi & 12 & 23,5 \\
Kararlar kısmen uygulandı & 20 & 39,2 \\
Hiç dikkate alınmadı & 19 & 37,3 \\
Toplam & 51 & 100,0 \\
\hline
\end{tabular}

Sürdürülebilir gelişmeye yönelik almış olduğu kararlarla ilgili katılımcılar, belediye yönetimlerinin bu kararların 12'sini (\% 23,5) "kararlar tamamen hayata geçirildi", 20 'si $(\%$ 39,2) "kararlar kısmen uygulandı", 19'u (\% 37,3) "hiç dikkate alınmadı" yanıtını vermiş̧tir (Tablo. 3). Sürdürülebilir bir kent gelecek nesiller için son derece önem arz etmektedir. YG 21 Programında da sürdürülebilir kentler için yerel yönetimlerin demokratikleşmesi ve kentle ile ilgili çalışmaların hızlandırılması üzerinde uzlaşı sağlanmıştır. Ancak Türkiye'de bu işlevi yürüten kent konseylerinin sürdürülebilir gelişmeler için almış olduğu kararların çoğunluğu ya kısmen uygulanmış $(\% 39,2)$ ya da hiç dikkate alınmamıştır (\% 37,3). Dolayısıyla YG 21 
Programına tam anlamıyla uyulmadığı ve sürdürülebilir gelişmelere yönelik alınan kararlar belediye yönetimleri tarafından yeterince dikkate alınmamıştır.

Tablo 4. Sivil toplumun gelişmesi ve sivil toplumun gelişmesine katkıda bulunmaya yönelik alınan kararlar

\begin{tabular}{lcc}
\hline \multicolumn{1}{c}{ Alınan Kararlar } & Sayı & $\%$ \\
\hline Kararlar tamamen uyguland 1 & 19 & 37,3 \\
Kararlar kısmen uyguland 1 & 20 & 39,2 \\
Hiç dikkate alınmadı & 12 & 23,5 \\
Toplam & 51 & 100,0 \\
\hline
\end{tabular}

Sivil toplumun gelişmesi ve sivil toplumun gelişmesine katkıda bulunmasına yönelik alınan kararlarla ilgili katılımcılar, belediye yönetimlerinin bu kararların 19’u(\% 37,3)“kararlar tamamen uygulandı", 20'si (\% 39,2) "kararlar kısmen uygulandı", 12'si (\% 23,5) "hiç dikkate alınmadı" yanıtını vermiştir (Tablo. 4). Kent konseylerinin en büyük özelliği sivil topluma vermiş olduğu katkıdır. Dolayısıyla kent konseyleri sivil toplumların gelişmesi için çalışmalar yapmaktadır. Ancak tablodaki verilere bakıldığında, kent konseylerinin sivil toplumun gelişimi için almış olduğu kararların yeterince uygulanmadığı, aksine çoğunluğunun $(\% 39,2)$ kısmen uygulandığ 1 görülmüştür.

Tablo 5. Kent yönetiminde saydamlık ve hesap verilebilirlik ile ilgili alınan kararlar

\begin{tabular}{lcc}
\hline \multicolumn{1}{c}{ Alınan Kararlar } & Say1 & $\%$ \\
\hline Kararlar tamamen uyguland 1 & 16 & 31,4 \\
Kararlar kısmen uyguland 1 & 18 & 35,3 \\
Hiç dikkate alınmadı & 17 & 33,3 \\
Toplam & 51 & 100,0 \\
\hline
\end{tabular}

Kent yönetiminde saydamlık ve hesap verilebilirlik ile ilgili alınan kararlarda katılımcılar, belediye yönetimlerinin bu kararların 16'sını (\% 31,4) "kararlar tamamen uygulandı", 18'i (\% 35,3) "kararlar kısmen uygulandı", 17'si (\% 33,3) "hiç dikkate alınmadı" yanıtını vermiştir (Tablo. 5). Kent yönetimi ile ilgili alınan kararların tüm halka açık ve şeffaf olması gerekir. Halkın kent ile ilgili alınan kararların varlığından haberdar olması için, yönetimin saydam ve hesap verilebilir bir yapıda olması gerekir. Dolayısıyla kent konseyleri kent yönetiminde saydamlığı ve hesap verilebilirliği artırmak için çalışmalar yapmakta ve kararlar almaktadır. Ancak tablodaki verilere bakıldığında, kararların çoğunlukla kısmen uygulandığı ya da hiç dikkate alınmadığ 1 görülmektedir.

\subsection{Kent Konseylerinin katılım Boyutuna Dair Bulgular}

$\mathrm{Bu}$ bölümde kent konseyleri toplantılarına vatandaşların yeterli düzeyde katılım sağlayıp sağlayamadığı elde edilen bulgularla değerlendirme yapılacaktır.

Tablo 6. Kent konseyi toplantılarına katılan kişiler aynı kişiler mi yoksa farklı kişiler mi?

\begin{tabular}{lcc}
\hline Kişiler & Say1 & $\%$ \\
\hline Aynı Kişiler & 15 & 28,8 \\
Farklı Kişiler & 17 & 71,2 \\
Toplam & 52 & 100,0 \\
\hline
\end{tabular}

Toplantılara katılan hemşeriler genellikle aynı kişiler mi yoksa farklı kişiler mi? Yargısına katılımcıların 15'i $(28,8)$ “aynı kişiler”, 37'si $(71,2)$ "farklı kişiler” yanıtı verilmiştir (Tablo. 6). Toplantılara katılan kişilerin farklı kişiler olması katılım ile beraber demokrasinin de işlevini ortaya çıkartmaktadır. Dolayısıyla kent konseylerinin demokrasi ile paralel bir şekilde varlığını devam ettirdiği görülmektedir. Bu kapsamda çoğunluğun $(\% 71,2)$ farklı kişileri 
belirtmesi yerel demokrasi için olumlu bir gelişmedir. Kent konseyleri işlevleri itibari ile katılımı, katılımda beraberinde yerel demokrasiyi ortaya çıkartmaktadır. Dolayısıyla kent konseyleri yerel demokrasi ve katılımcı bir kültür için önemli bir işlev görmektedir.

Tablo 7. Kent konseyi toplantılarına katılımcıların dışında hemşerilerin katılımı yeterli düzeyde oluyor mu?

\begin{tabular}{lcc}
\hline Kat1lım & Say1 & $\%$ \\
\hline Yeterli & 13 & 25,0 \\
Kismen Yeterli & 27 & 51,9 \\
Yetersiz & 11 & 21,2 \\
Kismen yetersiz & 1 & 1,9 \\
Toplam & 52 & 100,0 \\
\hline
\end{tabular}

Kent konseyi toplantılarına katılımcıların dışında hemşerilerin katılımı yeterli düzeyde oluyor mu? Yargısına katılımcıların 13'ü (\%2 5,0) “yeterli”, 27'si (\% 51,9) kısmen yeterli”, 11'i (\% 21,2) "yetersiz" 1'i de (\% 1,9) "kısmen yetersiz" yanıtı vermiştir (Tablo. 7). Verilen yanıtlara bakıldığında, kent konseyleri toplantılarına hemşerilerin yeterli düzeyde katılım gerçekleştirmedikleri görülmektedir. Ancak aktif katılımın sağlanması ve kentle ile ilgili alınacak olan kararlarda tüm halkın katılımının gerçekleşmesi gerekmektedir. Dolayısıyla kent konseyleri toplantıları katılım konusunda pasif kalmakta ve toplantılara katılım istenilen düzeyde gerçekleşmemektedir. Bu durum kentin demokratik değerlerinin geri planda kaldığını ve demokrasinin temel belirleyici ilkesi olan katılımın yetersiz kaldığını ortaya koymaktadır.

\subsection{Kent Konseyleri Ve Yerel Demokrasi İlişkisine Dair Bulgular}

Bu bölümde kent konseyleri ve yerel demokrasi ilişkisi üzerinde durulup, katılımcıların kent konseylerinin yerel demokrasiyi güçlendirip güçlendirmediğine dair değerlendirmeler üzerinde durulacaktır.

Tablo 8. Kent konseyinin bulunduğu yerdeki belediye yönetimi hangi siyasi partinin yönetimindedir?- kent konseylerinin yerel demokrasiyi güçlendirdiklerine inanıyor musunuz?

\begin{tabular}{lcccc}
\hline Siyasi Parti & $\begin{array}{c}\text { Kesinlikle } \\
\text { kat1liyorum }\end{array}$ & Katılıyorum & $\begin{array}{c}\text { Kesinlikle } \\
\text { katılmıyorum }\end{array}$ & Toplam \\
\hline AK Parti & $21(\% 72,4)$ & $7(\% 24,1)$ & $1(\% 3,4)$ & $29(\% 100,0)$ \\
\hline CHP & $17(\% 85,0)$ & $3(\% 15,0)$ & - & $20(\% 100,0)$ \\
\hline Diğer & $3(\% 100,0)$ & - & - & $3(\% 100)$ \\
\hline Toplam & $41(\% 78,8)$ & $10(\% 19,2)$ & $1(\% 1,9)$ & $52(100,0)$ \\
\hline
\end{tabular}

Kent konseyinin bulunduğu yerdeki belediye yönetimi hangi siyasi partinin denetimindedir?-Kent konseylerinin yerel demokrasiyi güçlendirdiklerine inanıyor musunuz? Yargısına Adalet ve Kalkınma Partili belediyelerin 21'i (\% 72,4) "kesinlikle katıliyorum", 7'si $(24,1)$ "katıliyorum", 1 tanesi "kesinlikle katılmıyorum" yanıtı vermiştir. Cumhuriyet Halk Partili belediyelerin 17'si (\% 85,0) "kesinlikle katıliyorum", 3’ü (\% 15,0) "kat1liyorum" yanıtı vermiştir. Diğer partilerin 3'ü (\% 100) ile "kesinlikle katılıyorum" yanıtı verildiği görülmüştür (Tablo. 8). Tüm siyasi partili belediye yönetimleri kent konseylerinin yerel demokrasi üzerinde etkili olduğu ve demokrasinin gelişimine yardımcı olduğu belirtilmiştir. Verilen yanıtlara bakıldığında tüm siyasi partiler, kent konseylerinin yerel demokrasiyi güçlendirdiğine inanmaktadır. Ancak Cumhuriyet Halk Partili belediye yönetimleri Adalet ve Kalkınma Partili belediye yönetimlerine göre daha yüksek (\% 85) oranda güven duygusu içerisindedir. Bu durum siyasi partilerin kent konseylerine olan bakış açılarını ve ebetteki yerel demokrasiye olan inanç ve güvenlerini ortaya koymaktadır. 
Tablo 9.Öğrenim durumunuz? kent konseylerinin yerel demokrasiyi güçlendirdiklerine inanıyor musunuz?

\begin{tabular}{lcccc}
\hline Öğrenim Durumu & $\begin{array}{c}\text { Kesinlikle } \\
\text { Katıliyorum }\end{array}$ & Katılıyorum & $\begin{array}{c}\text { Kesinlikle } \\
\text { Katılmiyorum }\end{array}$ & Toplam \\
\hline Lise & $2(\% 50)$ & $1(\% 25,0)$ & $1(\% 25,0)$ & $4(\% 100,0)$ \\
\hline Ön lisans & $6(\% 85,7)$ & $1(\% 14,3)$ & - & $7(\% 100,0)$ \\
\hline Üniversite & $22(\% 78,6)$ & $6(\% 21,4)$ & - & $28(\% 100,0)$ \\
\hline Yüksek Lisans & $8(\% 100,0)$ & - & - & $8(\% 100,0)$ \\
\hline Doktora & $3(\%$ 60,0) & $2(\% 40,0)$ & - & $5(\% 100,0)$ \\
\hline Toplam & $41(\% 78,1)$ & $10(\% 19,2)$ & $1(\% 1,9)$ & $52(\% 100,0)$ \\
\hline
\end{tabular}

Öğrenim durumunuz? -Kent konseylerinin yerel demokrasiyi güçlendirdiklerine inanıyor musunuz? Yargisına lise mezunu katılımciların 2'si (\% 50,0) "kesinlikle kat1liyorum", 1'i "katılıyorum", biri de "kesinlikle katılmıyorum" yanıtı vermiştir. Ön lisans mezunu katılımciların 6's1 (\% 85,7) "kesinlikle katılıyorum", 1'i ise "katıliyorum" yanıtını, lisans mezunu katılımciların 22'si (\% 78,6) "kesinlikle katıliyorum", 6's1 (\% 21,4) "kat1lıyorum" yanıtı vermiştir. Yüksek lisans mezunu katılımcıların 8'i (\% 100) "kesinlikle katılıyorum" yanıtını ve doktora mezunu katılımciların 3'ü (\% 60,0) "kesinlikle katılıyorum", 2'si (\% 40,0) "katılıyorum" yanıtı vermiştir (Tablo. 9). Öğrenim durumuna göre kent konseylerinin yerel demokrasiyi güçlendirdiğine inanıyor musunuz yargısına verilen cevapların çoğunluğu katılıyorum şeklindedir. Bu durum üzerinde şüphesiz eğitim düzeylerin yüksek olması etkili olmuştur. Eğitim düzeyinin artması ile birlikte bireylerin bilinçlendiği ve demokrasiye olan güven duygularının arttığı görülmektedir. Katılımcıların çoğunluğunun lise ve üstü bir eğitime sahip olması burumu destekler niteliktedir.

\section{Sonuç}

Demokrasi, dünyanın tüm ülkelerinde yöneten ile yönetilen ilişkisinde istenilen bir yaklaşım olmakla birlikte en çok tercih edilen bir yöntemdir. Tüm siyasi iktidarlar ve siyasal sistemler yapmış olduğu ya da yapacakları düzenlemeleri meşru göstermek için demokrasiyi kullanmaktadır. Demokrasinin yerel yönetimlerde karşılığı olan "yerel demokrasi" ise, "karar alma süreçlerine yerel halkın katılımının sağlanması", "yerel halkın kendini yönetimi", "yerel değerlerin demokratikleştirilmesi" şeklinde tanımlanabilir. Yerel halkın alınacak olan kararlarda söz sahibi olması, yerel sorunların ortak fikirler doğrultusunda tespit edilmesi, yerel kararların alımında önceliğin gözetilmesi ve kolektif yararın hedeflenmesi gibi faktörler demokrasinin temel yapısını göstermektedir.

Demokrasi ve yerel demokrasi sürecinin kendiliğinden gerçekleşmesi mümkün değildir. $\mathrm{Bu}$ sürece katkı sağlayacak yasal ve yapısal karar mekanizmaları gerekir. Bu kapsamda Türkiye'de yerel demokrasinin gelişmesi için 1990'lı yıllarda ilk adımları atılarak 2000'li yıllarda yasal boyutuna ulaşmıştır. 2000'li yıllardan sonra kent konseyi mekanizması ortaya çıkarak bu süreci hızlandırmıştır. Kent Konseyi mekanizması ile kentin hak ve hukukunun korunmasını sağlamak, sürdürülebilir kalkınmayı gerçekleştirmek, hemşerilik bilinci geliştirmek, çevreye duyarlılı̆̆ artırmak, şeffaf, hesap verilebilir, denetim ve katılım görevlerini yerine getirerek yerel demokrasinin gelişmesine katk1 sağlanmak istenmektedir.

Kent konseyleri farklı açılardan yerel demokrasiye katkı sağlayabilmektedir. Bu katkının sağlanabilmesi için kent konseyini mekanizmasının etkin bir şekilde çalışması gerekmektedir. Ancak çalışma içerisinde elde edilen bulgular, Türkiye'de kent konseylerinin etkin bir mekanizma içerisinde çalışmadığını göstermektedir. 
Kent konseylerinin kent kimliğine ilişkin tarihi, kültürel ve doğal değerlerini korunmaya yönelik almış olduğu kararların belediye yönetimleri tarafından çoğunluğu (\% 43,1) "tamamen hayata geçirildi” denilse de gerçek anlamda kararların uygulanma alanı bulmadığı görülmüştür.

Kent konseylerini ortak yaşam bilincinin geliştirilmesine yönelik alınan kararların yalnız \% 37,3'ü belediye yönetimleri tarafından tamamen hayata geçirilmiştir. Geriye kalan diğer kararlar ya kısmen uygulanmış ya da hiç dikkate alınmamıştır. Bu durum kentte ortak yaşam bilincinin geliştirilmesine yönelik alınan kararların aktif olarak uygulanmadığını ortaya koymuştur.

Kent konseylerinin sürdürülebilir bir kent için almış olduğu kararların \% 23'ü belediyeler tarafından hayata geçirilmiştir. Geriye kalan kararların çoğu ya kısmen hayata geçirilmiş ya da hiç dikkate alınmamıştır. Dolayısıyla sürdürülebilir bir kent için alınan kararların uygulamada sorunlarla karşılaştığı görülmüştür.

Kent konseylerinin sivil toplumun gelişmesine yönelik almış olduğu kararların çoğunluğu $(\% 39,2)$ kısmen uygulama alanı bulmuştur. Kent yönetiminde saydamlık ve hesap verilebilirlik ile ilgili alınan kararların yine çoğunlukla kısmen uygulandığg görülmüştür. Genel olarak bakıldığında, kent konseylerinin kent için almış olduğu kararların çoğunluğunu belediye yönetimleri tarafindan dikkate alınmadığı ve uygulamada sıkıntıların yaşandığı görülmüştür. Bu durum kentin demokratik değer ve tutumlarının arka planda bırakıldığını ve yerel demokrasinin bu süreçten zarar gördüğünü ortaya koymuştur.

Diğer yandan kent konseyi toplantılarına katılan hemşerilerin genellikle farklı kişiler olduğu, ancak toplantılara katılımın yeterli düzeyde olmadığ 1 görülmüştür. Yerel yönetimlerde etkin katılımın sağlanması ve yerel demokrasinin gelişimi için yerel halkın alınacak olan kararlara ve toplantılara aktif bir şekilde katılımı gerekmektedir. Ancak Türkiye'de yerel halkın gerçek anlamda kent konseyi toplantılarına katılım sağlayamadığı görülmüştür.

Kent konseylerinin yerel demokrasiyi güçlendirdiğine dair görüşe katılımcıların çoğunluğu "katılıyorum" yanıtı verdiği görülmüştür. Dolayısıyla katılımcılar kent konseylerinin yerel demokrasiyi güçlendirdiğine inanmaktadırlar. Kent konseylerinin yerel demokrasi üzerindeki etkilerinin artırılması ve demokratik değerlerin geliştirilmesi için, kent konseylerinin almış olduğu kararların belediye yönetimleri tarafından dikkate alınması gerekmektedir. Aksi halde alınan kararlar sadece teoride kalacak ve uygulama şansı bulamayacaktır. $\mathrm{Bu}$ durum, kentin demokratik değerlerinin arka planda kalmasına, yerel demokrasinin gelişmemesine, yerel halkın pasif bir pozisyonda kalmasına ve toplumsal değerlerin yok olmasına neden olacaktır.

\section{Kaynakça}

Atanur, G. (Ed.). (2016). Kırklareli ögrencilerinin kentlilik bilinci düzeylerinin tespitine ilişskin. Bursa: Bursa Kent Konseyi Bilimsel Yayınlar Dizisi-3.

Bağlı, M ve Binici, A. (2005). Kentleşme tarihi ve Diyarbakır kentsel gelişimi. Ankara: Bilim Adamı Yayınları.

Başbakanlık İletişim Merkezi. (https://www.bimer.gov.tr/) (Erişim: 10.05.2017).

Çevikbaş, R. (2008). Yerel yönetimlerde siyasal katılım. Türk İdare Dergisi, 2, 71-95.

Emrealp, S. (2010). Türkiye Yerel Gündem 21 Programı uygulamalarına yönelik kolaylaştırıcı bilgiler, İstanbul: UCLG- MEWA Yayını.

Gökçe, B. (1988). Toplumsal bilimlerde araştırma. Eskişehir: Seçkin Yayıncılık.

Görmez, K. (1997). Yerel demokrasi ve Türkiye. Ankara: Vadi Yayınları.

Gözler, K. (2017). Anayasa hukukuna giriş. Bursa: Ekin Basın Yayın Dağıtım.

Gözübüyük, A.Ş. (2006). Türkiye'nin yönetim yapısı. Ankara: Turhan Kitabevi. 
Harvey, D. (2012). Asi şehirler. (Temiz, A. D. Çev.) İstanbul: Metis Yayınları.

İçişleri Bakanlığı. (2006). Kent konseyi yönetmeliği. Ankara: Resmi Gazete.

Karataş, B. (2015). Araştırma teknikleri. İstanbul: Çağlayan Yayınları.

Kaypak, Ş. (2011). Katılımc1 yönetim mekanizması olarak kent konseyleri. Mustafa Kemal Universitesi Sosyal Bilimler Enstitüsü Dergisi, 7(14), 373-392.

Keleş, R. (1998). Yerinden yönetim ve siyaset. İstanbul: Cem Yayınevi.

Keskin, E.B. (2011). İstanbul büyükşehir belediyesi sinırlart içerisinde bulunan silivri ilçesi kent konseyi yapılanması ve gerçekleştirilen faaliyetler. Bursa, Bursa Kent Konseyi Bilimsel Yayınları Dizisi-1.

Keskin, E.B. (2011). Yerel demokrasi ve kent konseyleri. Bursa, Bursa Kent Konseyi Bilimsel Yayınları Dizisi-1.

Keskin, E.B. (Ed.) (2015). Kent konseylerinin mali kisitlart. Bursa: Bursa Kent Konseyleri Yayınları Dizisi.

Kocaoğlu, M. (2015). Yerel yönetimlerde katılım ve kültür. Konya: Çizgi Kitapevi Yayınları.

Küçükyılmaz, M. (2011). Türkiye'de siyasal katılım. İstanbul: İstanbul Matbaacılık.

Lefebre, H. (2014). Kentsel devrim. (Sezer, S. Çev.) İstanbul: Sel Yayıncılık.

Memişoğlu, D. (2015). Türkiye'de yerel yönetimlerin değişim ve dönüşümü. M. Mecek, M. Doğan \& B. Parlak (Ed.), İdari ve Mali Açıdan Türkiye'de Yerel Yönetimleri (51-65), Antalya: BEKAD Yayınları.

Mengi, A. (Ed.) (2007). Yerel yönetimlerde demokratikleşme ve halk katılımına etkisi bağlaminda internet ve toplumsal katmanlaşma. Ankara: İmge Kitapevi.

Özgür, H. (Ed.) (2007). Katılımcılık açısından belediye yasasının işlevselliği: kent konseyleri ve öteki mekanizmalar. Ankara: Nobel Yayın Dağıtım.

Parlak, B. (2015). Yerel yönetimler: kavramsal ve kuramsal çatı. M. Mecek, M. Doğan \& B. Parlak (Ed.), İdari ve Mali Açıdan Türkiye'de Yerel Yönetimler (5-35). Antalya: BEKAD Yayınları.

Pustu, Y. (2005). Yerel yönetimler ve demokrasi. Sayıştay Dergisi, 57, 121-134.

Seyidoğlu, H. (1995). Bilimsel araştırma ve yazma el kitabı. İstanbul: Güzem Yayınları.

Sunar, İ. (2010). Türkiye'de demokrasi serüveni. İstanbul: Doruk Yayınc1lık.

Şahin, Y. (2010). Kentleşme politikası. Trabzon: Murathan Yayınevi.

Taştekin, A. (2015). Yerel düzeyde katılımcı mekanizmalar olarak kent konseyleri. M. Mecek, M. Doğan \& B. Parlak (Ed.), İdari ve Mali Açıdan Türkiye'de Yerel Yönetimler (185-189) İçinde. Antalya: BEKAD Yayınları.

Türkiye Kent Konseyi Birliği. (http://www.kentkonseyleribirligi.org.tr/\#). (Erişim: 12.07.2017).

Üzan, N. (1999). Belediyeler ve yerel gündem 21. Çă̆daş Yerel Yönetimler Dergisi, 2, 96-100.

\section{ETIK ve BİLIMSEL İLKELER SORUMLULUK BEYANI}

Bu çalışmanın tüm hazırlanma süreçlerinde etik kurallara ve bilimsel atıf gösterme ilkelerine riayet edildiğini yazar(lar) beyan eder. Aksi bir durumun tespiti halinde Afyon Kocatepe Üniversitesi Sosyal Bilimler Dergisi'nin hiçbir sorumluluğu olmayıp, tüm sorumluluk makale yazarlarına aittir. 